\title{
A Cross-cultural Study of Mexico and the United States: Perceived Roles of Teachers
}

\author{
Gayle Nelson
}

Department of Applied Linguistics and ESL, Georgia State University, PO Box 4099, Atlanta, GA 30302-4099, USA

\section{Cindy Lutenbacher}

Department of English, Morehouse College, 830 Westview Drive, Atlanta, GA 30374, USA

\section{María Elena López}

American School Foundation of Monterrey, Rlo Missouri 555 Ote., Col. del Valle, San Pedro Garza Garcia, N.L. Mexico 66220

The high school graduation rate for Mexicans and Mexican Americans in the United States is approximately $\mathbf{5 0} \%$. This qualitative study investigated one area that may affect Mexicans' performance in American schools: cultural differences in appropriate school behaviour. Interview data were collected from 40 students and 20 teachers in Mexico in Spanish by native Spanish speakers, and from 20 native English-speaking students, 20 Mexican ESL students, 20 content area teachers, and 20 ESL teachers in the United States for a total of 140 participants. Students were in the fourth to eighth grades and teachers taught grades four to eight. Data analysis consisted of the following stages: (a) transcribing audiotapes, (b) listing all transcribed responses from each participant, (c) reconfiguring transcribed data so all responses to each item were listed together, (d) recursively reading responses to each item to identify patterns and coding categories, and (e) defining coding categories. Based on the categories, two raters coded the data. Not all data indicated differences between Mexico and the United States; however, one pattern of difference clustered around the issue of the role of the teacher. Mexican teachers were frequently perceived as relatively authoritarian but loving parents who were personally responsible for the learning of their students. American teachers, on the other hand, were perceived as less personally involved with students and as encouraging students' individual responsibility.

Numerous studies have documented the failure of American schools to successfully educate students of Mexican origin (Brown et al., 1980; Carter \& Segura, 1979; Orum, 1986). In 1990, the high school graduation rate for Mexican and Mexican American students was $54 \%$, whereas for whites it was $81 \%$ (Carter \& Wilson, 1993). The reasons for the 'leakage' of Mexican students from the 'educational pipeline' are complex (de los Santos, 1984: 68). Many theories have been proffered, including the concept of cultural mismatch. Ogbu (1992), for example, argues that it is not the content of the school that is difficult for Mexicans, but differences in style: cognitive style, interaction style and learning style. Ogbu and others suggest that what children bring to school - their communities' cultural models or understandings of the 'social realities' and the educational strategies that they, their families, and their communities use or do not use in seeking education - are as important as within-school factors (García \& Carrasco, 1981; Heath, 1983; Losey, 1997; Philips, 1972). 


\section{Review of Literature}

A body of research has looked at factors relating to the success or failure of Mexican students in schools. One set of studies has looked at how Mexican children learn at home. The Mexican mothers in Valdés' (1996: 147) study prepared their children for school by teaching them to be respectful and to behave: they were taught 'not to be disruptive, not to call attention to themselves, not to interrupt adult speech ...'.

Other studies have identified factors that may contribute to the success of Mexican students in American schools. Possible factors include a collective or cooperative classroom structure over an individualistic competitive one (Delgado-Gaitán, 1987; Engelbrecht, 1983; Losey, 1997); a classroom that has almost a familial relationship between student and teacher (Losey, 1997); teachers who really care about Mexican students (Valenzuela, 1999); teachers who do not cause students to lose face (Albert \& Nelson, 1993); and teachers who have high expectations of their students coupled with the belief that the students can achieve these high expectations (Chávez, 1997; García, 1991; Romo \& Falbo, 1996; Tikunoff, 1983).

Factors that may hinder Mexican students' progress in school include a number of subtle teacher behaviours that distance the student from the teacher, such as teachers calling on Mexican students less, praising them less, mispronouncing their names, and avoiding eye contact and physical closeness (Buriel, 1983; Losey, 1997); teachers evaluating the Mexican students negatively because they do not speak out loud, ask for the teacher's attention, volunteer, or call out answers (Valdés, 1996); students' lack of cultural knowledge as it relates to appropriate classroom behaviour and school procedures (García, 1999); and students' expectations that education in the United States is more like the Mexican concept of 'educación' which is based on respectful, caring relations between teachers and students as the basis for learning (Valenzuela, 1999).

Other factors that often affect Mexican students are leaving relatives and friends behind, difficult living conditions, feeling that other kids make fun of the way they speak; experiencing the stress associated with acculturation, and not feeling accepted by others (Gonzales \& Padilla, 1997; Goodenow, 1992; Kurtines \& Miranda, 1980; Padilla, 1986).

The studies reviewed in this paper investigated Mexican children in American schools. Little research has been published in English on Mexican students and teachers in Mexican schools and fewer, if any, have compared Mexican and American students' and teachers' perceptions of school-related issues.

The purpose of this study is to identify patterns of difference in the behaviours, expectations and attitudes of Mexican and American students and teachers. The overall research question is: What school-related differences emerge from the perceptions of American and Mexican students and teachers?

\section{Method}

The methodology used in this study can be described as qualitative interviews. Mexican teachers and students in Monterrey, Mexico were interviewed in Spanish by Mexicans; American teachers and students in Atlanta, Georgia were interviewed in English by Americans; and Mexican ESL students in Atlanta were 
interviewed in Spanish by a native Spanish speaker. Interviews were face-to-face and audiotaped. Because our goal was to look for patterns that emerged within a group (e.g. Mexican teachers) and to compare patterns from one group to patterns from another, interview questions were structured. Although traditional structured interviews leave little room for variation (Fontana \& Frey, 2000), the questions in this study were open-ended. The interviewer's role was that of an attentive listener. Because we were interested in understanding the interviewees' point of view, interviewers were trained in the qualities often associated with unstructured interviews; e.g. gaining trust and establishing rapport (Fontana \& Frey, 2000). As with other qualitative research, the results cannot be generalised beyond the participants in this study; however, they do suggest differences that may help American teachers understand the Mexican students in their classrooms. ${ }^{1}$

\section{Participants}

\section{United States}

Students. Participants met the following selection criteria. They (a) were in the fourth to eighth grade, (b) maintained a 3.0 grade point average, and (c) were in public schools in an urban area. In the United States, 20 native English-speaking (NES) students and 20 Mexican ESL students were interviewed. The NES students were interviewed in English by a native English speaker and the Mexican students were interviewed in Spanish by a native Spanish speaker. All of the Mexican students had studied in Mexico for at least one year before coming to the United States.

Teachers. Twenty NES content area teachers and 20 ESL teachers were also interviewed. Interviews were audiotaped and later transcribed. All teachers were from Atlanta, Georgia.

\section{Mexico}

Students. Participants (a) were in the fourth to eighth grade and (b) were selected by teachers as 'good' students. Forty students in the fourth, fifth, sixth or seventh grade were interviewed in Spanish by native Spanish-speakers. The audiotapes were transcribed into Spanish and also translated into English.

Teachers. Twenty Mexican teachers were also interviewed in Spanish. Teacher interviews were also transcribed into Spanish and translated into English.

Thus, a total of 80 Mexican and American students and 60 Mexican and American teachers were interviewed for a total of 140 participants.

\section{Interviews}

Items consisted of eight typical classroom scenarios, such as: 'If a student doesn't do his or her homework, what do you do?' The interview items (see Appendix) were developed by the researchers based on observations of Mexican and American classrooms and conversations with Mexican and American teachers. The student and teacher versions of the interview questions were the same. 


\section{Data Analysis}

Data analysis consisted of four stages. In stage 1, the audiotapes were transcribed so that the responses for each respondent were recorded and listed consecutively; (e.g. all of Student A's responses were recorded in the order that the questions were asked). In stage 2 , the data were reconfigured so that all responses to item 1 were listed consecutively. For instance, all Mexican student responses to interview item 1 were listed; all American student responses to item 1 were listed and so forth. In stage 3, two of the researchers recursively read through the responses to each question and let the data suggest the coding categories. Each question was different; the responses to each question were different; and thus, the coding categories for many questions were different. After the researchers had agreed and defined the appropriate categories for a group of questions, they independently coded the data. For all groups combined, intercoder reliability was $88 \%$. On those items for which there was disagreement, the coders referred back to the definitions of the categories and recoded until they reached agreement. Stage 4 consisted of identifying the patterns that emerged. A central pattern that emerged was perceived differences in the role of the teacher.

\section{Results}

Not all of our data showed distinctions between school experiences in Mexico and the United States. In many cases, both Mexicans and Americans responded similarly. In this paper, however, we focus on the differences because it is the differences that often cause misunderstandings between the two groups.

\section{Students drawing picture of teacher}

In this interview item, students and teachers were asked to respond to the following situation: 'A student draws a funny picture of the teacher which exaggerates a part of his or her body, like the stomach or hair. The student leaves the picture on the teacher's desk with no name on it, and the teacher discovers it'. American and Mexican students differed in their perceptions of how teachers would react in this situation. American native English-speaking students were about evenly divided between students who believed that the teacher would ignore the picture or treat it in a light-hearted way and students who believed that the teacher would either punish the whole class or find out and punish the individual responsible for it.

One female American student observed that good teachers recognise that students are going to make fun of them:

(1) A good teacher would probably just leave it alone because all kids are going to make fun of the teacher. They're the bad guy. (USNSFS4) ${ }^{2}$

Another student claimed that it depended on the personality of the teacher:

(2) It depends if she has a sense of humor or not. A teacher like ... would get really mad and probably paste it up and ask who did it. But most teachers would kind of laugh it off. (USNSFS8)

Virtually all of the Mexican students reported that they believed teachers would take it seriously. Most believed that the teacher would invariably find out who 
did it and punish that individual. The seriousness of the matter is illustrated by the following student comments, many of which indicate the student's punishment.

(3) Lo reporta a la dirección. Pues le llaman la atención y si no entiende, lo expulsan. (MXMS5)

(She reports the child to the office. They talk to the child and if he doesn't really see that it was wrong, he is suspended.)

(4) Le dice que nadie va al recreo hasta que digan quién fue. Cuando sabe quién fue, lo castiga con la detención. (MXMS2)

(She says that no one is going to recess until they tell her who did it. When she finds out who it was, she punishes him with detention.)

None of the Mexican students believed that the teacher would laugh or take it as a joke.

The teachers' responses are consistent with those of the students. American subject teachers and American ESL teachers largely considered this kind of behaviour or action to be of little or no consequence. Most said that they would either ignore the picture or make a joke of it. Some ESL teachers noted that they would put the picture up and use it for a language lesson on adjectives or body parts. One ESL teacher quipped:

(5) Oh, I'd probably just make a joke out of it. I might stick it up and say, 'Thank you for the picture!' I'd just make a joke out of it. Say, 'Yeah, you did a good job of drawing me'. I wouldn't get upset about that. (USESLTF2)

A content teacher stated:

(6) Ihang them up as long as they're not obscene. I think it's funny. (USCTM19)

In contrast, the Mexican teachers considered the behaviour to be a problem, and responded in a variety of ways. Most of the teachers said that they knew that they would be able to find out who did the drawing. About half of the teachers said they would discover who did the drawing and would have a private talk with the child. Three teachers said that they would have a talk with the child's parents and two said that they would bring in the school social worker. Respect emerged as a central theme throughout the responses. Some examples of a common response are:

(7) Bueno, no me ha sucedido eso nunca jamás. Pero pues qué tanto se puede hacer, llamarles la atención y decirles que no lo vuelvan a hacer, que no es correcto y es una falta de respeto para el maestro. Y que si yo los respeto a ellos pues ellos también deben que respetarme a mí. Porque yo no hago dibujos de ellos en el pizarrón, ni en ninguna parte, ni me burlo de ellos, ni nada, así que debe ser respeto mutuo.(MXTF6)

(That's never happened to me. But I would call their attention to it and tell them that it's wrong to do that and that it is a lack of respect for the teacher. And if I respect them, they have to respect me. Because I don't draw pictures of them, I don't make fun of them, so there should be mutual respect.)

(8) Si es anónimo ellos siempre saben quién fue. Preguntamos ¿Quién lo hizo? ¿Por qué lo hiciste así?, ¿Por qué me dibujaste así? ¿Tú crees que es correcto? ¿Estás 
burlándote de tu maestra? ¿Te falta el respeto? A ver ¿qué pasó?.... y hablo con los papás a ver qué está pasando. (MXTF14)

(If it's anonymous, they always know who it was. We ask, 'Who did this? Why did you do this? Why did you draw me like this? Do you think it's right? You make fun of your teacher? You have no respect? [You want] to see what happens? And I speak with the parents to see what's going on.)

These differences between Mexican and American students' and teachers' responses to this situation suggest a fundamental difference in the interpretation of respect as it relates to the role of the teacher. The Mexican responses suggest that the teacher is perceived as an authority figure whose dignity should not be abridged or burlesqued. The American responses, on the other hand, indicate that such an affront to the teacher is more acceptable, more in the nature of a childish display that would be tolerated.

\section{Students disagreeing with teacher}

In this interview item, students and teachers were asked to respond to this situation: 'A teacher says something that one of the students disagrees with. The student tells the teacher his/her point of view'. The majority of American students agreed that the teacher would either listen to and respect the student's opinion or utilise the disagreement for class discussion of the matter at hand. One female student noted that the quality of the student's comment would make a difference in how the teacher responded:

(9) If it is a good point of view and it's what they think, she would probably say, 'Well, that's your point of view and that's good that you have that point of view'. And if it's a good point of view, she would probably react to it, 'Thank you, that's very important because I probably missed that', or something like that. But if it's funny or something like that, she'd probably react like, 'Well, I'm not understanding what you're saying' or something like that. (USNSFS3)

Some students reported that the teacher's response would depend on the topic being taught in class (e.g. English grammar vs current events), and others noted that the response would depend upon the type of teacher:

(10) A strict teacher might not think it was funny and just say no, this is the way it is. A looser teacher would ask and say, 'Why do you think this?' Have a constructive discussion. (USNSFS13)

In contrast to the American students, almost all of the Mexican students believe that teachers, if challenged by a student, would present themselves as the authority. One student pointed out that it might be the students' fault that they did not understand and that the teacher will reprimand them:

(11) Pues estás platicando. Por eso es que no entiendes. (MXFS8)

([She tells the student that] he or she was talking and that is why he/she doesn't understand.)

Another student explained that the teacher would assert her authority as teacher, telling students to do what she says:

(12) Le dice que ella es la maestra y que tiene que hacer lo que ella dice. (MXMS9) 
(She tells the student that she is the teacher and that the students have to do what the teacher says.)

Students' responses indicate a belief that American teachers and Mexican teachers would react differently if a student disagreed with what they were saying. The American students believed that a teacher would either listen and respect the student's opinion and/or involve the class in a discussion about the particular point of disagreement. As with the responses to the funny picture situation, these responses suggest that the Mexican students generally agreed that teachers would claim themselves as authorities with the correct answer.

\section{Students complain of a boring activity}

In this interview item, students and teachers were given the following question: 'The students complained that an activity was difficult to understand and boring. They said they didn't want to do it but they didn't mind learning the material some other way'. American students were unanimous in their belief that teachers would make changes. Mexican students, however, indicated that many teachers would not change the activity.

A typical response from an American native English-speaking student was:

(13) Probably make up a game that we could play while we were doing it or put in some prises or a check mark for three points onto your grade. She'd try to get more students involved in doing this by making a game of it. (USNSFS10)

Mexican school students were about evenly divided between those who thought the best teacher would listen and make changes and those who thought the best teacher would not change his/her lesson plans. Among those who believed that the best teacher would not make changes, many noted accompanying instructions, such as asking the students to pay more attention or telling them that they need to be able to do these activities in order to pass to the next grade. A representative response among those who thought the teacher would not change the activity indicates a belief that the teacher is the authority figure:

(14) Les diría que no, que ella iba a decir qué vamos hacer. (MXFS13)

(She would tell the students she is the one who says what they have to do.)

Mexican ESL students in the American were largely in agreement that the teacher would change his/her methods, but only change by re-explaining the material using different words to convey the meaning.

Among the teachers there was almost total unanimity that they would listen to the students' ideas and change the activity. Only one American content teacher and one Mexican teacher noted that they would not change, and two Mexican teachers noted that they would consider the students' suggestions for use at a later date.

\section{Students not doing their homework}

Teachers and students were asked to respond to the situation: 'A student doesn't do his or her homework'. The American content area teachers were much more likely than Mexican teachers to be oriented toward rules or consequences that resulted from students not submitting their homework on time. Often the 
American teachers would not accept work if it were more than one day late. Examples of typical responses from content teachers are:

(15) It depends on how frequently they are not doing their homework. I had a very simple system. In my grade book I'd have blocks of ten, and they knew it would be $10 \%$ of their grade. Periodically, I'd mark off whether they'd done their homework. They could check it at any point. I set it up so they knew there was a cost to not doing it. (USCTF17)

(16) I reinforce my policy about homework. I use a homework form that the kids sign saying that they realise they had homework and they chose not to do it and I keep it on file. (USCTF6)

In contrast, most Mexican teachers expected the students to do the work. If students had not completed it at home then the teachers expected them to do it in school. The focus of the Mexican teachers was more on getting the work done some time rather than on time. Examples that illustrate this expectation are:

(17) Hay que motivarlos a que hagan la tarea. Hay que hacerles ver que es una obligación de ellos que tienen que traer la tarea, y si no en los ratos libres, y también en esos sitios hay que ponerlos a trabajar porque no terminaron su trabajo. (MXTF1)

(They have to be motivated to do their work. They need to know that it is their obligation to do it and they have to do it during free time (recess) because they did not finish their work.)

(18) Le pido que lo hagan en el salón de clases (MXTF19)

(I have them do it here in the classroom.)

Another difference between the American and Mexican teachers relates to the use of treats. If students completed their homework, some American teachers gave them treats such as candy, cupcakes, or prizes. If students did not complete their homework, teachers would withhold treats. For example, one American teacher responded:

(19) They get points for turning in their homework and at the end of the week they could turn in their points for prizes or something, you know, positive reinforcement. (USCTF5)

None of the Mexican teachers mentioned treats as a means of encouraging homework.

A related facet of the teacher's role in the relationship with students is the emphasis placed on the teacher's responsibility for seeing that students learn what they need to learn. Responses regarding a related question about students making up missed work during absences showed very similar patterns. The American content teachers placed much more emphasis on the responsibility of the individual to either make up the missed work or take the consequences of the actions. That is, the teacher may give the student the missed assignments, but would not offer supplemental support, instruction, or assistance to help students catch up. Additionally, more American content teachers expressed the sense that they would simply employ official school policy in responding to the issues of absences.

Many of the Mexican teachers responded differently. They would go to some length to work with students to catch up and make up the missed work. Such 
effort included meeting students during recess or after school to help them with missed work, coming to school on Saturday to give additional help, or even tutoring the student in the teacher's home. None of the Mexican teachers noted any use of school policy.

\section{Conclusion}

This paper focused on cultural differences in the roles of Mexican and American teachers and students as perceived by Mexican and American teachers and students. It is important to point out that what people believe would happen in a given situation may be different from what would happen during daily interactions. It is also important to point out that a great deal of diversity exists among teachers and students in both Mexico and the United States. The data in this study suggest patterns of behaviour, but many exceptions to the patterns exist. For example, not all Mexican teachers fulfil the role of a caring authoritarian parent.

Although there are exceptions to our findings, our data is consistent with the work of Valdés (1996) and Valenzuela (1999) who note that Mexican students are accustomed to a school environment that includes teacher-student relationships that resemble the relationships of parents with their children. More specifically, our data suggest that a teacher in Mexico is more likely to be perceived as a relatively authoritarian but loving parent, one who is personally responsible for the learning of the students. Respect for the teacher is very important and is shown through maintenance of the teacher's dignity. The American responses suggest a less hierarchical and more negotiated relationship, a relationship in which students may draw a caricature of or disagree with a teacher without causing the teacher to lose respect. These responses reveal that the Mexican notion of respeto goes beyond the English term respect. In Mexico, certain roles (and the people who occupy them) demand respeto based on the nature of the role (e.g. parents, teachers) and require particular kinds of behaviour (Valdés, 1996). As Valdés' study indicates, parents prepare their children for school not so much by teaching them academic content such as numbers and letters, but more by teaching them how to relate to their teachers respectfully. Valenzuela (1999) notes this connection in the Mexican ideal of 'educación', an ideal that places the teacher-student relationship as a cornerstone for all learning.

American teachers appear in our data to be somewhat more willing to allow students to 'get away with' some childish behaviours, but also to allow students room for individual failure and/or responsibility for their actions, such as turning in homework. This facet of the teacher-student relationship that values the individualism of self-expression may work against students who are more accustomed to a cooperative classroom structure (Delgado-Gaitán, 1992; Engelbrecht, 1983; Losey, 1997) and to teachers who consider it their personal responsibility to see that students behave respectfully and learn the necessary content.

The point here is not to criticise any teacher or group of teachers for their methods and approaches to teaching. The questions for consideration are more a matter of seeking to understand students. If students are accustomed to teachers in the parental, affectionate authority role, then how are they to interpret 
teachers whose style and approach offer a different role or image? If students from Mexico respond to a certain situation in a way that does not fit the American teacher's expectations, might there be a source for the response that originates in their expectations of the teacher-student relationship?

Teachers have choices from a range of responses, all of which may be quite natural, authentic, and 'real'. The more teachers know about what kinds of experiences and expectations their students may bring with them to their classrooms, then the better informed teachers' choices can be. So, for example, if teachers have reason to believe that some of their students may interpret their responses in a way that suggests they do not respect themselves (such as how teachers respond to the 'funny picture'), then teachers can choose to respond in another way. Or if teachers believe they are teaching individual responsibility (for homework or work missed during an absence), but have reason to believe that some students may interpret their actions as lack of caring, then teachers may adapt their behaviour to the culture of the students.

Knowing that one has choices of responses or action at any given moment and that a variety of student interpretations is likely may seem daunting initially. However, part of the growth that teachers must do is to develop a deeper understanding of students and of their lives, experiences, cultures, values and expectations. Learning to embrace knowledge of cultures different from one's own, and learning to suspend assumptions about students while growing toward a deeper connection with them constitute a pedagogical framework upon which teacher-student relationships and the consequent success of students may depend.

\section{Acknowledgements}

We extend thanks to Elvia Camaña, Vanessa Loggiodice, and John Bunting for helping to collect the data, to Maura Nicholson for her help in collating the data and careful editing, to Lourdes Ortega for editing the Spanish data, and to the many students and teachers who gave freely, and often enthusiastically, of their time in answering our questions. This research would not have been possible without an internal grant provided by the Research Office of Georgia State University and a release-time grant from Morehouse College.

\section{Correspondence}

Any correspondence should be directed to Prof. Gayle Nelson, Co-Chair, Associate Professor, Dept of Applied Linguistics and ESL, Georgia State University, PO Box 4099, Atlanta, GA 30302-4099, USA (gnelson@gsu.edu).

\section{Notes}

1. In writing this paper, we focused on cultural differences because differences, rather than similarities, more often result in negative interpretations of behavior. In addition, we focused on one aspect of the educational context: perceived role of the teacher. We recognise, however, that the context of each individual classroom is more complex than this study reports. It would be informative and useful to supplement the results of this study with classroom ethnographic research. The results of such studies would shed light on the subtleties of classroom behaviours. 
2. The coding conventions are as follows: $M X=$ Mexican; US=United States; $N S=$ native speaker; ESL=English as a second language; $\mathrm{S}=$ student; $\mathrm{T}$ =teacher; $\mathrm{F}=$ female; $\mathrm{M}=\mathrm{male}$, number=subject number.

\section{References}

Albert, R.D. and Nelson, G.L. (1993) Hispanic/Anglo-American differences in attributions to paralinguistic behavior. International Journal of Intercultural Relations 2, $19-40$.

Brown, G.H., Rosen, N.L., Hill, S.T. and Olivas, M.A. (1980) The Condition of Education for Hispanic Americans. Washington, DC: National Center for Education Statistics.

Buriel, R. (1983) Teacher-student interactions and their relationship to student achievement: A comparison of Mexican-American and Anglo-American children. Journal of Educational Psychology 75, 889-897.

Carter, D. and Wilson, R. (1993) Minorities in Higher Education, 1992. Eleventh Annual Status Report. Washington, DC: American Council on Education (ERIC Document Reproduction Service No. ED 363250 ).

Carter, T.P. and Segura, R.D. (1979) Mexican Americans in School: A Decade of Change. New York: College Entrance Examinations Board.

Chávez, R.C. (1997) A Curriculum Discourse for Achieving Equity: Implications for Teachers When Engaged with Latina and Latino Students. Washington, DC: Hisponic Dropout Project.

de los Santos, A.G., Jr. (1984) The connection between postsecondary programs for Hispanics and elementary and secondary schools. In S.H. Alpophus (ed.) Equality Postponed: Continuing Barriers to Higher Education in the 1980's (pp. 68-84). New York: College Entrance Examination Board.

Delgado-Gaitán, C. (1987) Parent perceptions of school: Supportive environments for children. In H. Trueba (ed.) Success or Failure?: Learning and the Language Minority Student (pp. 131-155). Cambridge, MA: Cambridge University Press.

Delgado-Gaitán, C. (1992) School matters in the Mexican-American home: Socializing children to education. American Educational Research Journal 29 (3), 495-513.

Englebrecht, G. (1983) And now Domingo: In school in the United States. Childhood Education 60 (2), 90-95.

Fontana, A. and Frey, J.H. (2000) The interview: From structured questions to negotiated text. In N.K. Denzin and Y.S. Lincoln (eds) Handbook of Qualitative Research (2nd edn) (pp. 645-672). Thousand Oaks, CA: Sage.

García, E.E. (1991) Effective instruction for language minority students: The teacher. Journal of Educationzo 17, 130-141.

García, E.E. and Carrasco, R.L. (1981) An analysis of bilingual mother-child discourse. In R.P. Durán (ed.) Latino Language and Communicative Behavior (pp. 257-270). Norwood, NJ: Ablex.

García, O. (1999) Educating Latino high school students with little formal schooling. In C. Faltis and P. Wolfs (eds) So Much to Say (pp. 61-82). New York: Teachers College, Columbia University.

Gonzales, R. and Padilla, A.M. (1997) The academic resilience of Mexican American high school students. Hispanic Journal of Behavioral Sciences 19, 301-317.

Goodenow, C. (1992) School Motivation, Engagement, and Sense of Belonging Among Urban Adolescent Students. ERIC Document Reproduction Service No. 349364.

Heath, S.B. (1983) Ways with Words. Cambridge, MA: Cambridge University Press.

Kurtines, W. and Miranda, M. (1980) Differences in self and family role perceptions among acculturating Cuban American college students. International Journal of Intercultural Relations 4, 167-184.

Losey, K.M. (1997) Listen to the Silences: Mexican American interaction in the Classroom Community. Norwood, NJ: Ablex.

Ogbu, J.U. (1992) Understanding cultural diversity and learning. Educational Researcher 21 (8), 5-14.

Orum, L.S. (1986) The Education of Hispanics: Status and Implications. Washington, DC: National Council of La Raza. 
Padilla, A.M. (1986) Acculturation and stress among immigrants and later generation individuals. In D. Frick, H. Hoefert, H. Legewie, R. Mackensen and R.K. Silbereisen (eds) The Quality of Urban Life: Social, Psychological, and Physical Conditions (pp. 100-120). Berlin: de Gruyter.

Philips, S.U. (1972/1985) Participant structures and communicative competence: Warm springs children in community and classroom. In C.B. Cazden, V.P. John, and D. Hymes (eds) Functions of Language in the Classroom (pp. 370-394). Prospect Heights, IL: Waveland.

Romo, H.D. and Falbo, T. (1996) Latino High School Graduation: Defying the Odds. Austin, TX: University of Texas Press.

Tikunoff, W.J. (1983) Compatibility of the SBIF Features with other Research Instruction of LEP Students. San Francisco: Far West Laboratory.

Valdés, G. (1996) Con Respeto: Bridging the Distances Between Culturally Diverse Families and Schools. New York: Teachers College Press.

Valenzuela, A. (1999) Subtractive Schooling: US-Mexican Youth and the Politics of Caring. New York: State University of New York Press.

\section{Appendix: Teacher interview questions (Questions were adjusted for students.)}

(1) You are explaining a difficult subject and two students in front of you are talking to each other all the time. What would you do?

(2) Suppose a student has missed a lot of classes because of personal reasons. The student comes up to you after class to explain why she or he has been absent. What would you do?

(3) If a student doesn't do his or her homework, what do you do?

(4) If all the students complained that an activity was impossible to understand and boring and said they didn't want to do it but they didn't mind learning the material some other way. What would you do?

(5) You are trying to explain something to the class. Almost everyone understands except one student. What do you do?

(6) You say something that one of the students doesn't agree with. The student tells you his or her point of view. What do you do?

(7) You are conducting a lesson and all of a sudden a student begins to cry. What do you do?

(8) A student draws a funny picture of you, which exaggerates a part of your body, like the stomach or hair. The student leaves the picture on your desk with no name on it, and then you discover it. What do you do? 